\title{
LANGUAGE ENVIRONMENT BASED ON MULTIPLE INTELLIGENCES AT ISLAMIC BOARDING SCHOOL
}

\author{
Ubaid Ridlo \\ Universitas Islam Negeri Syarif Hidayatullah Jakarta, Indonesia \\ Jl. Ir. H. Juanda, Tangerang Selatan, Banten, 15412, Indonesia \\ CorrespondingE-mail:ubaid.ridlo@uinjkt.ac.id
}

\begin{abstract}
The purpose of this study was to find and analyze informal language environment based on multiple intelligences theory, and to find the achievements of Darul Muttaqien Islamic Boarding School Bogor in learning Arabic, both academic and non-academic achievements.

This research was field research conducted at Tarbiyatul Mu'allimin wal Mu'allimât al-Islamiyyah (TMI) class II and class V which is equivalent to the level of Madrasab Tsanawiyah class II and Madrasah Aliyah class II Darul Muttaqien Islamic Boarding School Bogor since July 2017 up to August 2018. This research was qualitative, using case study methods with steps: a) Analysis of findings continuously in the field, b) Grouping and organizing data, c) Making systematic notes and reading literature about other studies about relevant issues to obtain a framework that fits the findings in the field, and d) Evaluate each of the steps taken to avoid mistakes or sharpen the focus of the ongoing research. Data collection methods were in-depth interviews, participant observation, focus group discussions, and documentation. There were two types of data in this study: First, primary data was obtained from interviews, observation results, Focus Group Discussion results, and Lessson Plan/RPP/I'dâd Tadrîs, informal language environments, and learning evaluation. Second, secondary data is obtained from books, research journals, magazines, print and electronic media. This study proved that learning Arabic with Howard Gardner's Multiple intelligences theory approach has a positive effect and very effective in improving students' language skills. Islamic boarding school with integrated, integrative and comprehensive education system has applied this theory in the process of learning Arabic, both in class and in the Islamic boarding school environment with the support of kyai, teachers, and representative facilities.
\end{abstract}

Keywords: $\quad$ Multiple Intelligences, Arabic Learning, Islamic Boarding Schools, Language Environment

\section{Introduction}

The success of education cannot be separated from the learning process, which includes several interrelated components. These components are teachers, students, materials, media, and method. In the learning process, a teacher is required to be able to create and use various methods, so that learning is not boring for students. But so far, the learning process that takes place in the world of education is still centered on the teacher, not on students. 
So far, education in Indonesia considers human intelligence too narrow, humans are considered to have only one intelligence that can be measured, they call it logic-mathematical intelligence, while the tool used to measure intelligence is an IQ test. The results of neuropsychological research show that human potential that has been actualized is still very minimal, only about $10 \%$. This is motivated by learning patterns that only focus on the development of academic intelligence (verbal linguistic intelligence and mathematical logic), especially in formal education. Whereas humans have been provided with various types of intelligence (multic intelligence) that demand to be developed to the expected limits. This has led to a shift in the educational trend of the $21^{\text {st }}$ century which has begun to be oriented towards the development of human potential and no longer focuses on technical abilities in the exploration and exploitation of nature as the $20^{\text {th }}$ century education trend ${ }^{1}$.

$21^{\text {st }}$ century education requires a learning pattern that is more empowering for students' intelligence. The principles of education put forward by UNESCO, as quoted by E. Mulyasa, that education must be placed on four pillars, namely learning to know, learning to do, learning to live together, learning to be, and life long learning ${ }^{2}$ requires learning patterns that are able to develop all the intelligences of students.

However, there are quite a number of neuroscientists who describe schools as "half-brain" institutions because in education and teaching activities it is very demanding for children to gain skills in the left hemisphere ${ }^{3}$. The reality of formal learning models that only respect and rely on all educational activities and teaching on two types of intelligence alone, namely mathematical logical intelligence and verbal linguistic intelligence that has castrated the multicompetitive potential of its students ${ }^{4}$. The dominance of learning patterns that only focus on the two types of intelligence, results in the color of the curriculum, learning strategy, type of evaluation or assessment as well as various ongoing education policies.

This condition is questioned by Howard Gardner ${ }^{5}$ with his theory related to multiple intelligences ${ }^{6}$ trying to dismantle the IQ paradigm. He emphasized that IQ

${ }^{1}$ Melvin L. Silberman, Active Learning: 101 Strategies to Teach Any Subject, (Massachusettts: Allyn and Bacon Boston, 2006), 15. See also Sarjuli, et.al., Active Learning: 101 Strategi Pembelajaran Aktif, (Yogyakarta. YAPPENDIS 2007), 13.

${ }^{2}$ E. Mulyasa, Kurikulum Berbasis Kompetensi, (Bandung: Rosda Karya, 2006), 5.

3 Bob Samples, Open mind/Wholemind: Parenting and Teaching Tomorrow's Children Today, (Torrance USA: Jalmar Press, 1999), 76. See also Rahmani Astuti, Revolusi Belajar Untuk. Anak: Panduan Belajar Sambil Bermain Untuk Membuka Pikiran Anak-Anak Anda, (Bandung: Kaifa, 2006), 74.

${ }^{4}$ Gordon Dryden dan Jeanette Vos, The Learning Revolution: To Change The Way The World Learns, (Selandia Baru: The Learning Web, 1999), 95. See also Worlds Translation Service, Revolusi Cara Belajar (The Learning Revolution) Belajar akan Efektif Kalau Anda dalam Keadaan Fun', Bagian I: Keajaiban Pikiran, (Bandung: Kaifa, 2006), 99.

${ }^{5}$ Howard Gardner is a professor from Harvard University in the United States, he was a pioneer of Project Zero with his theory relating to Multiple Intelligences.

${ }^{6}$ Mustafa Zülküf Altan, "Intelligence Reframed: Multiple Intelligences for the 21st Century by Howard Gardner", TESOL Quarterly, Vol. 35, No. 1 (Spring, 2001), 204-205. See also Colleen A Ruggieri, "Multigenre, Multiple Intelligences, and Transcendentalism", The English Journal, Vol. 92, No. 2, Multigenre Teaching, (Nov., 2002), 60-68. 
has various weaknesses because it is only capable of measuring mathematical language and logical intelligence. Whereas according to Gardner human intelligence may be infinite and the mental complexity of humans cannot be measured by the IQ test. In his 1983 Frame of Minds Gardner proposed the concept of intelligence as a multifactor, consisting of seven separate dimensions, not just the construction of a single unit, according to Gardner, the seven intelligences are language, logical, visual, spatial, musical, kinesthetic, intelligence. interpersonal, and intrapersonal intelligence, lately in his book entitled Intelligence Reformed, Gardner adds naturalist, existential, and spiritual intelligence ${ }^{7}$. The theory eliminates the assumptions that have existed about human intelligence.

Learning by applying the multiple intelligences theory approach according to the author, can also be applied in all aspects of science/study, including Arabic. Learning Arabic with a multiple intelligences ${ }^{8}$ theory approach can be a solution in the midst of the turmoil of teachers/clerics/lecturers/instructors and students in the process of teaching and learning Arabic. Almost can be found at all levels/levels of education of pesantren and non-pesantren, both Ibtidaiah Madrasah, Madrasah Tsanawiyah, Madrasah Aliyah, Islamic Higher Education, most students feel that learning Arabic is difficult, complicated, and so on. Likewise, the learning process makes learners feel uncomfortable, enjoy, and not empowered by their intelligence resources, so that the results are less than optimal and disturbing all interested parties.

Thus learning Arabic requires enlightenment in almost all aspects ${ }^{9}$. For example, there is a lack of a conducive language and cultural environment and supports the achievement of the main objectives of learning Arabic. The Arabic learning curriculum that was developed also still does not apply the multiple intelligence $^{10}$ theory approach. The presence of native speakers (Arabic) has not

\footnotetext{
${ }^{7}$ Howard Gardner, Intelligence Reformed: Multiple Intelligences For the $21^{\text {st }}$ Century, (New York: Basic Books, 1999), 47.

${ }^{8}$ Daniel Fasko, "An Analysis of Multiple Intelligences Theory and its Use with the Gardner, Howard dan Thomas Hatch, Multiple Intelligences Go to School: Educational Implications of the Theory of Multiple Intelligences", Educational Researcher, Vol. 18, No. 8, Nov. 1989, 4-10", http://www.jstor.org/stable/1176460, Accessed: 13/07/2017 23:20. See also Howard Gardner, Reflections on Multiple Intelligences: Myths and Messages", The Phi Delta Kappan, Vol. 77, No. 3, Nov. 1995, 200-203, 206-207, http://www.jstor.org/stable/20405529, Accessed: 13/07/2016 23:34.

${ }^{9}$ According to Prof. Dr. H.D. Hidayat, MA, there are at least three factors that are the source of difficulties / problems in teaching Arabic in Indonesia, namely: 1. Linguistic problems, 2. Sociological and psychological problems, and 3. Methodological problems. This research focuses on methodological aspects.

${ }^{10}$ Carol Jago, Vicky Greenbaum, and Linda Hecker, "Multiple Intelligences", The English Journal, Vol. 85, No. 3, The Universe of Literature, March 1996, 10-11, http://www.jstor.org/stable/820094, Accessed: 13/07/2016 22:16. See also Janet McClaskey, "Assessing Student Learning through Multiple Intelligences", The English Journal, Vol. 84, No. 8, Multiple Intelligences, Dec. 1995, 56-59, http://www.jstor.org/stable/821191, Accessed: 13/07/2014 23:35. See also McMahon, Susan D., Dale S. Rose, and Michaela Parks, "Multiple Intelligences and Reading Achievement: An Examination of the Teele Inventory of Multiple Intelligences", The Journal of Experimental Education, Vol. 73, No. 1, Fall 2004, 41-52, http://www.jstor.org/stable/20157383, Accessed: 13/07/2014 22:18
} 
colored Arabic learning. At the same time, almost all Arabic language competence skills are less than optimal.

To reinforce the above statement, the authors convey the results of research related to multiple intelligences-based learning that has been successful in the learning process. For example Abdul Basid's research"1, Tadrîs al-Lughah al-'Arabiyyah 'ala Asâs Ta'addud al-Drakâ': Babtsun Tajribiy fî Madrasah Anak Shâlih al-Ibtidâiyyah Malang". This study succeeded in proving that learning Arabic with multiple intelligences theories can improve speaking and writing skills. Likewise research conducted by Emir Eka Putra Rayesh ${ }^{12}$, his research entitled Relationship of Learning Style with Multiple Intelligences of Students Achieving Class IV and V Elementary School (SD/MI) in Malang City proved that there was a significant relationship between learning styles with multiple intelligences of fourth grade achieving students and V SD/MI in Malang City means students have their own type of intelligence because according to the learning style they have. This was in line with what Abidin discussed About the strategy of developing multiple intelligences in madrasab as one of the Islamic educational institutions. ${ }^{13}$

From all the descriptions above, the research on language environment based on Multiple Intelligences is very much to be carried out, and as a case study this dissertation research is Darul Muttaqien Bogor Islamic Boarding School. The pesantren was chosen by the author with several academic and scientific considerations as follows:

1. Darul Muttaqien Islamic Boarding School Bogor is one of the leading Islamic education institutions in the Bogor area of West Java with a progressive and worldwide vision and mission ${ }^{14}$.

2. Arabic learning at Darul Muttaqien Islamic Boarding School for Tarbiyatul Mu'allimin wal Mu'allimât (TMI) level uses Dual System, which is the incorporation of Nazhariyah al-Wahdah (Integrated System/All in One System) and Nazariyah al- Furu'.

3. Darul Muttaqien Islamic Boarding School Bogor has a myriad of achievements in the academic and non-academic fields, including achievements in learning Arabic.

${ }^{11}$ Abdul Basid, “Tadris al-Lughah al-'Arabiyyah 'ala Asas Ta'addud al-Dzaka': Bahtsun Tajribiy fi Madrasah Anak Shalih al-Ibtidaiyyah Malang”, Tesis, Universitas Islam Negeri Maulana Malik Ibrahim Malang, 2011.

12 Emir Eka Putra Rayesh, "Hubungan Gaya Belajar dengan Multiple Intelligences Siswa Berprestasi Kelas IV dan V SD/MI di Kota Malang", Tesis, Universitas Islam Negeri Maulana Malik Ibrahim Malang, 2016.

13 Zainal Abidin, "Pengembangan Kecerdasan Majemuke (Multiple Intelligences) di Madrasab", Elementary: Jurnal Ilmiah Pendidikan Dasar, Vol 3, No. 2, 120-131. Doi http://dx.doi.org/10.32332/ elementary.v3i2.832

14 Interview with Dr. Ahmad Sastra, MM (Leader of Darul Muttaqien Islamic Boarding School in Bogor), on December 20, 2017. See also Tim PP Darul Muttaqien, Profil Pondok Pesantren Darul Muttaqien Parung Bogor, (Bogor: PP Darul Muttaqien, 2015), 47-50. 
Ara6iyât Jurnal Pendidikan Bahasa Arab dan Kebahasaaraban, 6 (1), 2019

According to preliminary research by the author, Bogor Darul Muttaqien Islamic Boarding School has tried to apply multiple intelligences theory as an approach to learning Arabic compared to educational institutions generally in the West Java and surrounding areas.

\section{Literature Review}

Writing about studies of intelligence is quite a lot, some are in the form of books and research. Among the works that are relevant to this research according to the authors are:

Emir Eka Putra Rayesh ${ }^{15}$, Hubungan Gaya Belajar dengan Multiple Intelligences Siswa Berprestasi Kelas IV dan V SD/MI di Kota Malang, (Postgraduate of the State Islamic University Maulana Malik Ibrahim Malang, 2016). The purpose of this thesis research is to explain what learning styles and multiple intelligences possessed by high achieving students in grades IV and V in Malang City. Then explain the relationship between learning styles with multiple intelligences of achieving students in grades IV and $\mathrm{V}$ in $\mathrm{SD} / \mathrm{MI}$ in Malang City. This research is a correlational study, which is knowing whether there is a significant relationship between learning styles and multiple intelligences of high achieving students in grades IV and V SD/MI in Malang City (MIN Malang 2, SDN Kauman 1, and SDN Purwantoro 1) with samples of all fourth grade students and V as many as 150 students, then to find out the relationship between the two variables only requires 96 students. Data collection methods use questionnaires, odd semester UAS report cards and data of high achieving students in each school. The data analysis technique used is product moment that is looking for the relationship of learning styles with multiple intelligences of high achieving students. The results showed that there was a significant relationship between learning styles and multiple intelligences of achieving students in grades IV and V SD/MI in Malang City, meaning students had their own type of intelligence because they matched the learning styles they had.

Heriyanti ${ }^{16}$, Tadwîr al-Mawâd li Ta'lim Mahârah al-Kitâbah 'ala Asâs al-Drakâât alMuta'addidah bi al-Tatbîq' ala Thalabah Madrasah al-Munirah al-Mutawasitah al-Islamiyyah Ujungpangkah Gresike, (Postgraduate of the State Islamic University Maulana Malik Ibrahim Malang, 2016). The purpose of this thesis research is to produce teaching material products for multiple intelligence based writing skills. This study strengthens that learning material developed based on multiple intelligences theories can improve student achievement in Arabic (writing Insya 'guided).

15 Emir Eka Putra Rayesh, "Hubungan Gaya Belajar dengan Multiple Intelligences Siswa Berprestasi Kelas IV dan V SD/MI di Kota Malang.

16 Heriyanti, "Tadwir al-Mawad li Ta'lim Maharah al-Kitabah 'ala Asas al-Dhaka at alMuta'addidah bi al-Tatbiq 'ala Thalabah Madrasah al-Munirah al-Mutawasitah al-Islamiyyah Ujungpangkah Gresik”, Tesis, Universitas Islam Negeri Maulana Malik Ibrahim Malang, 2016. 
Amir Mukminin ${ }^{17}$, I'dâd al-Mawâd al-Ta'limiyyah fi Mahârah al-Kalâm 'ala Asâs alDhakâât al-Muta'addidah bi Madrasah Wahid Hasyim al-Mutawasitah al-Islamiyyah Ponorogo East Java, (Postgraduate of the State Islamic University Maulana Malik Ibrahim Malang, 2017). The aim of the theological research is to produce teaching material products for multiple intelligence-based speaking skills in order to improve the quality of learning. The conclusion of this study is that teaching materials developed for learning multiple intelligence-based speaking skills are effective in improving students' ability to speak.

Mu'min ${ }^{18}$, Comprehensive Intelligence-Based Learning Management: Multisite Study in SD Plus Mutiara Bangil and SD Mutiara Ilmu Pandaan, (Postgraduate of the State Islamic University of Maulana Malik Ibrahim Malang, 2016). This dissertation explains that education in Indonesia in the face of global competition requires graduates who have the ability to think, adapt and compete globally. For that the optimization of the development of the entire potential of students becomes a necessity. Gardner's multiple intelligence theory bridges the world of education towards the development of various intelligences. To realize the success of multiple intelligence-based learning requires good management. This study aims to analyze and discover the concepts, implementation and implications of multiple intelligence-based learning management in SD Plus Mutiara Bangil and SD Mutiara Ilmu Pandaan. The conclusion of the study shows that management of multiple intelligence-based learning has positive implications for the development of intelligence, personality, and abilities of students, teacher's managerial abilities and public trust in schools.

\section{Method}

Type of Research

This type of research is qualitative research that takes the place of research is field (field research). Qualitative research reveals data in depth and extracts information as deeply as possible through the data provided ${ }^{19}$. This research uses a case study method. The case study method ${ }^{20}$ is a series of scientific activities carried out intensively, in detail and in depth about a program, event, and activity, either at the level of individuals, a group of people, institutions, or organizations to obtain in-depth knowledge of the event. Usually, the chosen event, referred to as the case is the actual (real-life events), which is in progress, not something that has passed. In addition, this study also requires the collection of data and information with the help of various

17 Amir Mukminin, "I'dâd al-Mawâd al-Ta'limiyyah fi Mahârah al-Kalâm 'ala Asâs al-Dhakâât alMuta'addidah bi Madrasah Wahid Hasyim al- Mutawasitah al-Islamiyyah Ponorogo East Java”, Disertasi, Universitas Islam Negeri Maulana Malik Ibrahim Malang, 2017.

18 Mu'min, "Manajemen Pembelajaran Berbasis Kecerdasan Majemuk: Studi Multisitus di SD Plus Mutiara Ilmu Bangil dan SD Mutiara Ilmu Pandaan”, Disertasi, Universitas Islam Negeri Maulana Malik Ibrahim Malang, 2016.

${ }_{19}$ Nurul Zuriah, Metodologi Penelitian Sosial dan Pendidikan, (Bandung: Bumi Aksara, 2006), 107.

${ }^{20}$ Mudjia Rahardjo, Studi Kasus dalam Penelitian Kualitatif: Konsep dan Prosedurnya, (Malang: UIN Maulana Malik Ibrahim, 2017), 1-5. 
materials in the form of books and other documents ${ }^{21}$. Because of that what is done is digging up information and analyzing a number of data, both primary data and secondary data.

\section{Data Sources}

Data sources needed in this study are primary sources and secondary sources:

a. Primary data is data obtained from field research through interviews, results of observations, focus group discussions (FGD), and documentation related to this research, namely informal language environment at Darul Muttaqien Islamic Boarding School in Bogor.

b. Secondary data includes: data that is sourced indirectly related to this research that is documentation, both from books, research journals, magazines, print and electronic media

\section{Data Collection Method}

The methods used in data collection are:

a. In-depth interview (indepth interview). This is done in order to get information directly from the resource person or interview in depth without any psychological obstacles between the two.

In this study acting as informants as follows:

a) Leadership of Bogor Darul Muttaqien Islamic Boarding Schools

b) Principals of MTs and MA

c) Deputy Principal

d) 10 Subject Teachers of Arabic Language

e) 3 Dormitory Coach

f) 50 students of class VIII MTs and XI MA / Class 2 and 5 TMI

g) Parents of Student VIII grade MTs and XI MA / Class 2 and 5 TMI

h) Graduate

From the above informants, it is expected to be able to provide information and information widely about the data regarding the process of learning Arabic based on the theory of multiple intelligences.

b. Participant Observation. In this method, observations are made based on direct experience, by being involved in the learning process in the classroom and outside the classroom. This is to obtain data that is natural about learning Arabic based on multiple intelligences theories, namely learning methods,

${ }^{21}$ Anton Bakker \& Ahmad Charis Zubair, Metodologi Penelitian, (Yogyakarta: Kanisius, 1992), 10. 
learning media, informal language environments, and evaluation of learning at the research location.

c. Focus Group Discusssion. Joint discussion activities between researchers and research subjects were directed. This focus group discussion can be preceded by the selection of discussion members that have been previously determined by the researcher. In the implementation of focus group discussions, the researchers carried it out with principals, vice principals, teachers, and dormitories.

d. Documentation ${ }^{22}$. This is done to find data about things or variables in the form of notes from books, newspapers, magazines, etc. that are directly related to the theme of multiple intelligences, learning Arabic, Islamic boarding schools, or things related to this research.

\section{Data Analysis Techniques}

Data analysis techniques carried out are descriptive analytical. In other words, focusing attention on the problems examined as they are, the results of the research are then processed and analyzed to draw conclusions. Data analysis activities are carried out simultaneously throughout the study period. The steps of analysis are carried out in an effort to understand and interpret the data obtained which includes the following activities ${ }^{23}$ :

a. Analysis of findings continuously in the field, especially in problems that are thoroughly and also in the overall phenomena related to research questions, with the aim of getting big themes and to develop concepts produced in the research.

b. Grouping and organizing data, as soon as possible after data is obtained so that it can assist researchers in understanding the problem patterns and themes of the phenomenon under study.

c. Make systematic notes and read the literature about other studies on relevant issues to obtain a framework that fits the findings in the field.

22 Suharsimi Arikunto, Prosedur Penelitian Suatu Pendekatan Praktek, (Jakarta: Rineka Cipta, 2002), 206. See also Noeng Muhajir, Metode Penelitian Kualitatif, (Yogyakarta: Rakesarasin, 2007), 101.

${ }^{23}$ Nana Syaodih Sukmadinata, Metode Penelitian Pendidikan, (Bandung: Rosda Karya, 2011), 99. See also Durri Andriani, dkk, Metode Penelitian, (Jakarta: Universitas Terbuka, 2011), 621. Compare with Mudjia Rahardjo's opinion that the steps of the case study are as follows: a. The researcher reads the entire transcript to obtain general (general) information from each transcript; b. These general messages are compiled for specific messages (specific messages), c. From these special messages will be known the general pattern of data. Furthermore, the data can be grouped according to the sequence of events, categories, and typologies. As is usually the case in qualitative research, Case Study data analysis begins when researchers in the field, when collecting data and when the data has been collected all. And it is important to note that the flow of qualitative research, including the case study method is flexible, can be inductive or deductive. See also Mudjia Rahardjo, Studi Kasus dalam Penelitian Kualitatif: Konsep dan Prosedurnya, (Malang: UIN Maulana Malik Ibrahim, 2017), 18-19. 
d. Evaluate every step taken to avoid mistakes or sharpen the focus of research that is being carried out continuously.

\section{Approach}

This study used several approaches, namely the neuropsycholinguistic ${ }^{24}$ approach, which is a branch of psycholinguistics that examines the relationship between language, language, and the human brain. The analytical tool in this study was the theory of intelligence according to Howard Gardner, namely the theory of Multiple Intelligences. This theory is used by the author as an approach in analyzing Arabic learning data at the Darul Muttaqien Islamic Boarding School in Bogor. The sociology approach was used to explain the facts that actually occured in the field regarding the pattern of interaction between teachers and students in the learning process. Meanwhile, the research approach was a qualitative approach. Qualitative research has characteristics ${ }^{25}$, namely: First, naturalistic. Qualitative research has an actual background as a direct source and researchers are a key instrument. Second, descriptive data. Data were collected by taking the form of words or images compared to numbers. Third, dealing with the process, this research concentrated more on the process than the results or products. Fourth, inductive ${ }^{26}$. The data owned by the researchers were analyzed inductively. Fifth, meaning. The meaning is essential care for the qualitative approach. Also, a philosophical approach was used to see the phenomenon behind the object under study ${ }^{27}$.

\section{Result and Discussion}

Language and environment are two things that cannot be separated. Language is a medium used in the interaction between one person and another, while the environment is a place where language grows and develops. Language is simply defined as a means used by humans to communicate with others in an environment. With language a person can express their feelings, ideas, ideas so that they can be understood by others, and vice versa.

${ }^{24}$ In this case, the author uses Howard Gardner's neuro concept, namely multiple intelligences because the author considers the easiest and simplest to be used by educational practitioners such as teachers and clerics in educational institutions. The Multiple Intelligences approach in the context of the world of practical education, generally nullifies complex statistical formulas, the Stanford Binet IQ intelligence tests, the Paul Mac Lean version of the "triune" brain, Oka Oki's Roger Sperry theory, the Franz Joseph Gall Frenology concept, and others. other.

${ }^{25}$ Emzir, Metodologi Penelitian Kualitatif: Analisis Data, (Jakarta: Rajawali Press, 2010), 2-4.

${ }_{26}$ And it is important to note that the flow of qualitative research analysis, including the case study method is flexible, can be inductive or deductive. This means that case study method research can produce new theories, strengthen existing theories, or just find something new (New Finding). See also Mudjia Rahardjo, Studi Kasus dalam Penelitian Kualitatif: Konsep dan Prosedurnya, (Malang: UIN Maulana Malik Ibrahim, 2017), 15-23.

${ }^{27}$ Abudin Nata, Metodologi Studi Islam, (Jakarta: Raja Grafindo, 2014), 49. 
Understanding the new language above at the level of function, has not explained the actual form of language. Experts provide an explanation of the various forms of language. Language according to Soenjono Dardjowidjojo is an arbitrary oral symbol system used by members of a language community to communicate and interact with each other, based on the culture they share ${ }^{28}$. Harimurti Kridalaksana explained that language is an arbitrary symbol of sound system used by members of social groups to work together, communicate, and identify themselves ${ }^{29}$. Abdul Chaer stated that language is a symbol system in the form of sound, which is arbitrary, productive, dynamic, diverse and humane ${ }^{30}$.

Of the several definitions put forward by the experts above, there are several characteristics or characteristics of the language, including: 1) The system means that the language is formed by a number of components that are patterned permanently and can be assigned; 2) Symbol of sound, the language system in the form of sound symbols, which is commonly called the sound of words or sounds of meaningful language; 3) Arbitration, meaning that the relationship between the symbol symbolized by it is not obligatory, can change, and it cannot be explained why the symbol embodies a particular meaning. Even so, the symbols of language are also conventional, meaning speakers of a language will adhere to the relationship between the symbols symbolized by them; 4) Productive, meaning with limited elements, but can be made almost unlimited speech; 5) Dynamic, meaning that the language is inseparable from various possible changes that can occur at any time; 6) Diverse, meaning that despite having the same specific rules but because it is used by heterogeneous speakers, with different social backgrounds and habits, making the language diverse, both phonological, morphological, syntactic, and lexicon; 7) Humane, meaning that language as a verbal communication tool is only possessed by humans $^{31}$. The characteristics and nature of this language are based on general linguistic views. As for the sociolinguistic view of language, it has characteristics as a communication tool and self-identifying tool.

The language environment for learners is everything around the learner that has meaning and/or influence on language skills. Because the language that is related to language is usually in the form of sound/symbol and symbol (writing) the language environment is related to these two things. This is in line with the definition of the language environment that Heidi Dulay, et al. that is, everything the language learns hears and sees in the new language ${ }^{32}$.

${ }^{28}$ Soenjono Dardjowidjojo, Psikolinguistik: Pengantar Pemahaman Bahasa Manusia, Jakarta: Yayasan Obor Indonesia, 2003), 16.

${ }^{29}$ Harimurti Kridalaksana, Kamus Linguistike, (Jakarta: Gramedia, 1983), 21. 1995), 14.

30 Abdul Chaer dan Leonie Agustina, Sosiolinguistik: Perkenalan Awal, (Jakarta: Rineka Cipta,

31 Mansoer Pateda, Aspek-Aspek Psikolinguistik, (Jakarta: Nusa Indah, 1990), 25-26. See also Muhammad Farkhan, An Introduction To Linguistics, (Jakarta: UIN Jakarta Press, 2006), 9-14. See also Abdul Chaer dan Agustina, Sosio Linguistik: Perkenalan Awal, (Jakarta: Rineka Cipta, 1995), 15-19.

32 Heidi Dulay, et.al., Language Two, (Oxford: Oxford University Press, 1982), 13. 
This statement affirms that the language environment is any situation, whether intentional or not, which sounds and shows someone the new language they learn. These situations include: teaching and learning in the classroom, conversations while at home, in a restaurant or in a shop, conversations with friends, dialogues heard when watching television/movies, when reading textbooks, newspapers and magazines, writings found on the street (in the form of flyers, advertisements, logos and banners), and so on. The various situations mentioned can be classified into two types of language environment, namely: environment which is intentionally formed in such a way as to learn language for learners such as those taking place in educational/school institutions or called formal environments; and an environment in which the language learned is used and found by the learner not only during language classes in school/class but also in daily communication where the learner is located or known as a non-formal environment ${ }^{33}$.

In order to implement the Arabic-speaking environment based on multiple intelligences theory which includes nine intelligences, namely linguistic intelligence (language), visual-spatial intelligence, musical intelligence, interpersonal intelligence (social), mathematical logical intelligence, kinesthetic intelligence, intrapersonal intelligence, naturalist intelligence, and spiritual intelligence. Darul Muttaqien Bogor Islamic Boarding School makes a daily, weekly, monthly and annual activity program ${ }^{34}$. Among others are ${ }^{35}$ :

\section{Daily activities}

Santri Language Coaching (Ilqâ' al-Mufradât)

The aim of this program is to improve the quality of students' language skills. The target is students from grades 1-6, held twice a day; namely at 05.15-05.35 Submission of a new mufradat, 21.15-21.30 Repetition and submission of duties,

33 Ahmad Fuad Effendy, Metodologi Pengajaran Bahasa Arab, (Malang: Misykat, 2005), 165

${ }^{34}$ Interview with Dr. Ahmad Sastra, MM (Leader of Darul Muttaqien Islamic Boarding School in Bogor), on December 15, 2017, interview with Hendrizal Rasyid, SS (Head of Madrasah Aliyah Islamic Boarding School Darul Muttaqien Bogor), interview with Abdullah Hudri, SS, M.Pd (Madrasah Tsanawiyah Head Darul Muttaqien Bogor Islamic Boarding School, and on December 15, 2017, and the results of interviews with Ust. Masyur, S.Pdi (Deputy Head of the Darul Muttaqien Islamic Boarding School Tsanawiyah Madrasah), on December 15, 2017. See also Tim PP Darul Muttaqien, Materi Orientasi Wali Santri TMI (Tarbiyatul Mu'allimin wal Mu'allimat al-Islamiyyah) Pesantren Darul Muttaqien: Satu dalam Aqidah, Toleransi dalam Khilafiyah, Berjama'ah dalam Ibadah, (Bogor: DM Press, 2017), 6.

35 Interview with Ust. Imron Wachidi, S. Pd (Head of Childcare PP Darul Muttaqien Bogor), on December 18, 2017, interview with Ust. Imam Bagja N, S. Sos I (Head of Care for Princess PP Darul Muttaqien Bogor), on December 18, 2017, Interview with Ust. Ihya Ulumuddin (Secretary of the Head of Care for the Son and Daughter of Darul Muttaqien Bogor Islamic Boarding School) on December 18, 2017, interviewed Abdullah Hudri, SS, M. Pd (Head of Madrasah Darul Muttaqien Islamic Boarding School Tsanawiyah), and on December 15, 2017, interview with Ust. Masyur, S. Pd.I (Deputy Head of the Madrasah Islamic Boarding School Darul Muttaqien Islamic Boarding School), on December 15, 2017 
located in front of their respective rooms. Technical Implementation of Mufradat Coaching is as follows ${ }^{36}$ :

1. Santri already knows the place of guidance

2. Mudabbir opens activities by reading the basmalah together

3. Mudabbir submits two new vocabulary words, students follow

4. Mudabbir gives an example by placing two new vocabulary words in perfect sentences

5. Mudabbir appoints some santri to make examples of perfect sentences with two new vocabulary given

6. As an evaluation material, young people give the task to students to put new vocabulary in perfect sentences

7. Mudabbir attend santri.

8. Mudabbir provides motivation about the importance of language

9. Mudabbir closes coaching by reading hamdalah

\section{Material}

1. Students of grade 1 and intensive use the book of the 1 st Gontor mufradat collection

2. Class 2 students use the second book of the Gontor mufradat

3. Grade 3 students use the 2 nd book of the Gontor mufradat

4. Students of grades 4-6 (Aliyah) use the third book of the Gontor mufradat collection

\section{Dialogues and Arabic Music Screening}

Screening of dialogue and Arabic-language music is intended so that students can listen to stories, conversations, or music in Arabic in the dormitory.

a. Aim

1. Form the language and soul of the language

2. Improve the quality of students' understanding of Arabic

b. Time every morning and take place in the dormitory

c. Manager: OPDM language section (lighting).

d. Implementation Conditions

${ }^{36}$ Interview with Dr. Ahmad Sastra, MM (Leader of Darul Muttaqien Islamic Boarding School in Bogor), on December 15, 2017, interview with Hendrizal Rasyid, SS (Head of Madrasah Aliyah Islamic Boarding School Darul Muttaqien Bogor), interview with Abdullah Hudri, SS, M. Pd (Madrasah Tsanawiyah Head Darul Muttaqien Bogor Islamic Boarding School, and on December 15, 2017, and the results of interviews with Ust. Masyur, S. Pdi (Deputy Head of the Darul Muttaqien Islamic Boarding School Tsanawiyah Madrasah), on December 15, 2017. See also Tim PP Darul Muttaqien, Materi Orientasi Wali Santri TMI (Tarbiyatul Mu'allimin wal Mu'allimat al-Islamiyyah) Pesantren Darul Muttaqien: Satu dalam Aqidah, Toleransi dalam Khilafiyah, Berjama'ah dalam Ibadah, (Bogor: DM Press, 2017), 6. 
Arabiyât Jurnal Pendidikan Bahasa Arab dan Kebahasaaraban, 6 (1), 2019

1. OPDM Prepare hiwar or music that you want to convey in Arabic or English

2. OPDM Provides tape or mp3 player to play hiwar or songs

3. Santri listens to hiwar or music carefully

\section{Reading Arabic Announcements}

Announcement in Arabic in the form of delivering important information from the Darul Muttaqien Student Organization (OPDM) for all students to be used to listening to announcements in Arabic in mosques and dormitories ${ }^{37}$.

a. Aim

1. Form the language and soul of the language

2. Improving the quality of students' understanding of Arabic or English

3. Convey information - important information from OPDM for students

b. Time after Islamic prayer and conditional prayer and take place in a mosque or dormitory

\section{Communication in Arabic}

Familiarize students to speak using the official language, namely Arabic. The targets are all students of Tarbiyatul Mu'allimin wal Mu'allimat al-Islamiyyah (TMI) Darul Muttaqien Islamic Boarding School, while the target is that students are used to speaking using Arabic as a means of oral communication, therefore students are required to use Arabic in daily communication - day, the person in charge of this program is Mudabbir, OPDM in the Language section, and Language Advisor ${ }^{38}$. Thus this activity trains students to be linguistic intelligent, intrapersonal.

${ }^{37}$ Interview with Ust. Imron Wachidi, S. Pd (Head of Childcare PP Darul Muttaqien Bogor), on December 18, 2017, interview with Ust. Imam Bagja N, S. Sos I (Head of Care for Princess PP Darul Muttaqien Bogor), on December 18, 2017, Interview with Ust. Ihya Ulumuddin (Secretary of the Head of Care for the Son and Daughter of Darul Muttaqien Bogor Islamic Boarding School) on December 18, 2017, interviewed Abdullah Hudri, SS, M. Pd (Head of Madrasah Darul Muttaqien Islamic Boarding School Tsanawiyah), and on December 15, 2017, interview with Ust. Masyur, S. Pd.I (Deputy Head of the Madrasah Islamic Boarding School Darul Muttaqien Islamic Boarding School), on December 15, 2017.

38 Interview with Ust. Imron Wachidi, S. Pd (Head of Childcare PP Darul Muttaqien Bogor), on December 18, 2017, interview with Ust. Imam Bagja N, S. Sos I (Head of Care for Princess PP Darul Muttaqien Bogor), on December 18, 2017, Interview with Ust. Ihya Ulumuddin (Secretary of the Head of Care for the Son and Daughter of Darul Muttaqien Bogor Islamic Boarding School) on December 18, 2017, interviewed Abdullah Hudri, SS, M. Pd (Head of Madrasah Darul Muttaqien Islamic Boarding School Tsanawiyah), and on December 15, 2017, interview with Ust. Masyur, S. Pd.I (Deputy Head of the Madrasah Islamic Boarding School Darul Muttaqien Islamic Boarding School), on December 15, 2017. 


\section{Do'a Malam (Praying before Sleeping)}

Familiarizing students to listen to announcements in official language, the target is all santri Tarbiyatul Mu'allimin wal Mu'allimat al-Islamiyyah (TMI) Islamic Boarding Schools Darul Muttaqien. The target is that students are used to listening to announcements in official languages. The procedure is Division I'lam guiding students to pray at night using official language together using loudspeakers. The person in charge is the Student Organization Darul Muttaqien (OPDM) part of the Ilam (Announcement). This program trains students to be spiritually intelligent, linguistic intelligent, and intelligent interpersonally.

Weekly activities

Speech Exercise (Mubâdarah)

a. Purpose

1. Add knowledge to students

2. Develop students' learning talents and interests

3. Form an independent, honest and skilled soul to students

4. Improve physical and spiritual health to students

5. Give students a new atmosphere for achievement

b. The target is class $1-5$

c. Implementation Time:

Every Sunday and Monday are divided into three sessions:

1. Sunday, 13.30 - 14.55 WIB (English)

2. Sunday, $20.00-21.20 \mathrm{WIB}$ (Arabic)

3. Monday, $20.00-21.20$ WIB (Bahasa)

4. The place of implementation of the mubâdarah in a predetermined class

Conversation ${ }^{39}$ Program (Mubâdatsab)

a. Purpose

1. Train santri in correct language pronunciation

2. Familiarize students to apply language in a day

3. Improve the quality of students' language skills

39 Linguis said that "speaking is language". Speaking is the ability to pronounce articulation sounds or words to express, express or convey thoughts, ideas, and feelings. Speech as a way of communicating greatly influences the lives of individual human beings. In this system, people exchange opinions, feelings, and desires. And this system is what gives effectiveness to individuals in establishing mental and emotional relationships with other members. Presumably there is no need to doubt that the magnitude of the role of language and communication in human life. See Henry Guntur Tarigan, Berbicara sebagai Suatu Keterampilan Berbahasa, (Bandung: Angkasa Bandung 2008), 9. 
Ara6iyât Jurnal Pendidikan Bahasa Arab dan Kebahasaaraban, 6 (1), 2019

b. The target is students of grade 1 s.d. 4

c. The execution time is twice a week (Tuesday and Friday 05.00 - 05:30)

d. Place of Implementation in front of the dormitory

e. Guidance Stages Muhâdatsah

1) Santri already knows the place of formation

2) Mudabbir opens activities by reading the basmalah together

3) Mudabbir instructs santri to follow the material read

4) Mudabbir does question and answer with students

5) Santri did question and answer with students/question and answer in pairs

6) As an evaluation material, the students give questions to 2 to 3 students

7) Mudabbir attend santri.

8) Mudabbir provides motivation about the importance of language

9) Mudabbir closes coaching by reading hamdallah

f. Material: the first and intensive class students use the muha $>$ dathah book by Ustadz Aqshadi Rakadi

\section{Wall Magazine Program}

\section{Objectives and goals}

a. Purpose

1. Instilling interest in writing in Arabic

2. A place to channel writing skills

b. Target

1. Students are able to write news sections in Arabic

2. Students can channel writing skills.

\section{Implementation}

1) Time and place; this activity is held once a week, precisely on Sunday.

2) Technical implementation; the weekly language magazine is coordinated by the Darul Muttaqien Student Organization (OPDM) section of the Language by assigning Language Club and Mc Club members. Rubrics include; article, idom-idom, vocabulary (al-Mufradât) illustrated story, conversation (alMubâdatsah), and the official report at Pondok Pesantren. Weekly Magazines will be exhibited for the next week.

\section{Tasyji 'al-Lughah Program}

a. Purpose

1. Improve the quality of students' language skills

2. Motivate students to speak

3. Familiarize students with using language in everyday life 
4. Make it easier for students to understand lessons that use language

b. The target of this program is all students of Darul Muttaqien Islamic Boarding School in Bogor

c. Time every Monday at 4:00 a.m. to 4:30 p.m. and housed in the mosque

d. Tasyji 'al-Lughah's Guiding Stages ${ }^{40}$

1. Santri already know the place of guidance

2. Motivators open activities by reading the basmalah together

3. Motivators convey material

4. Motivator invites santri to always communicate with official language

5. Motivator closes by reading hamdalah

\section{Language Court}

The aim of this program is to discipline students in Arabic. The target is the students of class 1-4. The place is in the mosque and in the Lughah Court room, held after the Isha prayer. While the person in charge is the Darul Muttaqien Student Organization (OPDM) Language Section whose role is to punish students who violate language. The forms of punishment vary, for example cleaning toilets, running around the field, becoming jasus (looking for language violators), and other educating penalties.

\section{Monthly activities ${ }^{41}$}

Language Club Meeting

The purpose of this activity is to optimize language activities in the dormitory. Participants of this meeting are members of the language club consisting of the beginning lughah, section i'lam, language section, and language guide. This meeting aims to plan and evaluate language activities in the dormitory, the responsible party is the Darul Muttaqien Student Organization (OPDM) Language Department and Language coach.

${ }^{40}$ Interview with Ust. Imron Wachidi, S. Pd (Head of Childcare PP Darul Muttaqien Bogor), on December 18, 2017, interview with Ust. Imam Bagja N, S. Sos I (Head of Care for Princess PP Darul Muttaqien Bogor), on December 18, 2017, Interview with Ust. Ihya Ulumuddin (Secretary of the Head of Care for the Son and Daughter of Darul Muttaqien Bogor Islamic Boarding School) on December 18, 2017, interviewed Abdullah Hudri, SS, M. Pd (Head of Madrasah Darul Muttaqien Islamic Boarding School Tsanawiyah), and on December 15, 2017, interview with Ust. Masyur, S. Pd.I (Deputy Head of the Madrasah Islamic Boarding School Darul Muttaqien Islamic Boarding School), on December 15, 2017.

${ }^{41}$ Interview with Ust. Imron Wachidi, S. Pd (Head of Childcare PP Darul Muttaqien Bogor), on December 18, 2017, interview with Ust. Imam Bagja N, S. Sos I (Head of Care for Princess PP Darul Muttaqien Bogor), on December 18, 2017, Interview with Ust. Ihya Ulumuddin (Secretary of the Head of Care for the Son and Daughter of Darul Muttaqien Bogor Islamic Boarding School) on December 18, 2017, interviewed Abdullah Hudri, SS, M. Pd (Head of Madrasah Darul Muttaqien Islamic Boarding School Tsanawiyah), and on December 15, 2017, interview with Ust. Masyur, S. Pd.I (Deputy Head of the Madrasah Islamic Boarding School Darul Muttaqien Islamic Boarding School), on December 15, 2017. 


\section{Arabic Bulletin}

The target of this program is to increase the creativity of santri in Arabic, especially communication in the form of writing, the participants are all students of Tarbiyatul Mu'allimîn wal Mu'allimât al-Islâmiyah (TMI) Islamic Boarding School Darul Muttaqien. The person in charge of the Darul Muttaqien (OPDM) Student Organization Language Department will issue a bulletin containing students' work in Arabic.

\section{Annual Activities ${ }^{42}$}

\section{Language Competition / Musâbaqah Lughawizyah}

The aim of this program is to improve students' Arabic language skills. The participants were all santri Tarbiyatul Mu'allimîn wal Mu'allimât al-Islâmiyah (TMI) Darul Muttaqien Islamic Boarding School; between rayon and force. While the language skills contested are reading Arabic poetry, Arabic-language plays, Arabic speeches, and others. The person in charge of this program is the Darul Muttaqien Student Organization (OPDM) in the Language section.

\section{Three Language Speech Contest}

The aim of this program is to improve the ability to speak santri using Arabic, English and Indonesian. The participants are santri class 1 s.d. 4, The responsible person is the Darul Muttaqien Student Organization (OPDM) Language Department.

\section{Drama Contest}

The aim of this program is to improve the creativity of santri in Arabic. The participants are santri class 1 s.d. 4 arranged according to the mubâdatsah group. The person in charge of this program is the Student Organization of Darul Muttaqien (OPDM) Section of Language and Parts of mubâdatsah.

\section{The Language World Activities}

The purpose of this activity is to improve the creativity of santri in Arabic. The participants are santri Tarbiyatul Mu'allimîn wal Mu'allimât al-Islâmiyah (TMI) Darul Muttaqien Islamic Boarding School class 1 s.d. 4. The types of skills contested are

42 Interview with Ust. Imron Wachidi, S. Pd (Head of Childcare PP Darul Muttaqien Bogor), on December 18, 2017, interview with Ust. Imam Bagja N, S. Sos I (Head of Care for Princess PP Darul Muttaqien Bogor), on December 18, 2017, Interview with Ust. Ihya Ulumuddin (Secretary of the Head of Care for the Son and Daughter of Darul Muttaqien Bogor Islamic Boarding School) on December 18, 2017, interviewed Abdullah Hudri, SS, M. Pd (Head of Madrasah Darul Muttaqien Islamic Boarding School Tsanawiyah), and on December 15, 2017, interview with Ust. Masyur, S. Pd.I (Deputy Head of the Madrasah Islamic Boarding School Darul Muttaqien Islamic Boarding School), on December 15, 2017. 
reading Arabic poetry, Arabic Broadcasting, Taqdim al-Qisshah al-'Arabiyyah, Arabic Speeches, Arabic Listening, Arabic Singing, and so on. The person in charge of this activity is the Language Section in collaboration with the Language Division to hold competitions between students and santriwati as a continuation of Language Competition,

\section{Internal Scouting Language}

The purpose of this activity is to improve the creativity of Arabic students. The participants are all santri Tarbiyatul Mu'allimin wal Mu'allimât al-Islamiyah (TMI) of the Darul Muttaqien Islamic Boarding School, while the person in charge is the Language Section in collaboration with the scout section holding camps where there are scout activities speak Arabic.

\section{Darul Muttaqien Language Festival (D'Lafest)}

Among the objectives of this activity is to improve students' Arabic language skills. The participants were all santri Tarbiyatul Mu'allimin wal Mu'allimât al-Islamiyah (TMI) of the Darul Muttaqien Islamic Boarding School, school and madrasah students, and pesantren santri in Jabodetabek. The type of competition is reading poetry, drama, speech, and so on. The person in charge of this activity is the Darul Muttaqien Student Organization (OPDM) in the Language section.

\section{National or International Arabic Language Colloquium}

One of the objectives of this activity is to motivate santri to love Arabic. The target of this activity is all santri Tarbiyatul Mu'allimin wal Mu'allimât al-Islamiyah (TMI) of the Darul Muttaqien Islamic Boarding School. The person in charge of this activity is the Darul Muttaqien Student Organization (OPDM) Language Section and Language Advisor who invites national or international Arabic experts.

From the description above, it can be concluded that the Santri Language Development Program can train nine santri intelligences, namely linguistic intelligence (language), visual-spatial intelligence, musical intelligence, interpersonal intelligence (social), mathematical logical intelligence, kinesthetic intelligence, intrapersonal intelligence, intelligence naturalist, and spiritual intelligence. intelligence, for example linguistic, intrapersonal, interpersonal, kinesthetic, and spiritual intelligence.

Therefore, it is only natural that the Darul Muttaqien Islamic Boarding School obtain achievements that should be proud, for example the value of institutional accreditation from the government gets A (Very Good). The education system of Darul Muttaqien Islamic Boarding School is called Tarbiyatul Mu'allimin wal Mu'allimât al-Islamiyah (TMI) for 6 years which is equivalent to Madrasah Tsanawiyah and Madrasah Aliyah. At the senior secondary level, the students can choose the Madrasah Aliyah education level (Social Studies and Natural Sciences Study Program). All levels of Madrasah Tsanawiyyah (MTs) and Madrasah Aliyah (MA) education have been 
accredited A. And Tarbiyatul Mu'allimîn wal Mu'allimât al-Islâmiyah (TMI) Darul Muttaqien Islamic Boarding School has gained Equality ( $M u^{\prime}$ adalah) from the Ministry of Religion of the Republic of Indonesia, Ministry of National Education, Islamic University of Madinah Saudi Arabia, Al-Azhar University Cairo Egypt, UIA Malaysia, United Arab Emirates, Pakistan, Jordan, and establish educational partnerships with several institutions in the Middle East and Europe. Likewise, students arrived from all corners of the country and some came from foreign countries, such as Malaysia, Thailand, the Philippines and others with a fairly rigorous and responsible selection.

In the academic field, santri Tarbiyatul Mu'allimîn wal Mu'allimât al-Islâmiyah (TMI) Darul Muttaqien Islamic Boarding School in Bogor succeeded in gaining a very proud score in the 2017-2018 Academic Year on behalf of Halida Maulidiah P (MTs) class $3 \mathrm{~F}$ with an average value of 93.20, and Ismi Muftahdina (MA) grade 5C with an average score of 93.82. In addition, it was found that the oral test results of Arabic subjects (Nahwu, Mahfuzat, Sharaf, Muthâla'ah, and Tamrinul Lughah) santri Tarbiyatul Mu'allimîn wal Mu'allimât al-Islâmiyah (TMI) Pondok Pesantren Darul Muttaqien Academic Year 2017/2018 the average score in the number is 80 sd 85 . With the highest score of 84 , and the lowest score of 77 . Likewise, it was found that the results of the tests wrote subjects of kebahasaaraban (Tamrinul Lughah, Nahwu, Insya', Mahfuzât, Sharaf, and Muthâla'ah) santri Tarbiyatul Mu'allimîn wal Mu'allimât al-Islâmiyah (TMI) Islamic Boarding School Darul Muttaqien odd semester 2017/2018 Academic Year the average score is $80 \mathrm{sd} 85$ with the highest score of 97.5, and the lowest score of 78. Likewise many santri who succeeded in obtaining scholarships abroad, for example al-Azhar Cairo Egypt, Islamic University Madinah Saudi Arabia, and Turkey.

In addition to academic achievement, students of Tarbiyatul Múallimîn wal Mu'allimât al-Islamiyah (TMI) Islamic Boarding School Darul Muttaqien also performed in non-academic fields. For example, the average mulya santri moral value Tarbiyatul Múallimîn wal Mu'allimât al-Islamiyah (TMI) in grade 2 and class 5 is in the Very Good criteria (91-100). With the highest score of 97.5 and the lowest value of 82.5. It was also found that the average value of the santri personality of Tarbiyatul Mu'allimin wal Mu'allimât al-Islamiyah (TMI) in grade 2 and class 5 was in the Very Good criteria (91100). With the highest score of 95 , and the lowest value of 85 . Other achievements in the non-academic field that have been achieved by Pesantren in the last three years are:

1. First winner in the environmental arrangement in the category of Islamic Boarding Schools in West Java

2. Third place in the national Arabic speech at PP Darunnajah Jakarta

3. Second place winner writes national level Arabic essay at PP Darunnajah Jakarta

4. Third place winner in the Bogor district level in Bogor

5. Winner of the Bogor District Arabic Speech at Parung KKM

6. First place winner of Arabic poetry at Bogor district at PP Darul Muttaqien Bogor 
Arabiyât Jurnal Pendidikan Bahasa Arab dan Kebahasaaraban, 6 (1), 2019

7. First place in high school Arabic debates throughout Jabotabek at UIN Jakarta And others

\section{Conclusion}

From the description and analysis, it can be concluded that the creation of a language environment, the facts on the ground show that Islamic boarding schools and the parties involved have succeeded in creating a varied and innovative Arabicspeaking environment, starting from daily, weekly, monthly and annual activities. Therefore, it is only natural that nine intelligences (Howard Garder's Multiple Intelligences Theory) have been applied. The nine intelligences are linguistic intelligence (language), visual-spatial intelligence, musical intelligence, interpersonal intelligence (social), mathematical logical intelligence, kinesthetic intelligence, intrapersonal intelligence, naturalist intelligence, and spiritual intelligence.And in the end, there were no results that betrayed all endeavors, thus the wise statement. Darul Muttaqien Bogor Islamic Boarding School has successfully delivered its students to the gates of academic and non-academic success in Arabic.

Then the advice that can be given by the researcher is to realize the language environment (bi'ah lughawiyyah), the Islamic Boarding School needs to bring in Arabic instructors and teachers from native speakers (native speaker/shâbib al-lughah) in a programmed time, for example one semester. This needs to be done to improve students' listening, speaking, reading, and writing skills from the results of interacting with shâhib al-lughah both in classrooms and pesantren environments.]

\section{REFERENCES}

Abidin, Zainal. "Pengembangan Kecerdasan Majemuk (Multiple Intelligences) di Madrasah", Elementary: Jurnal Ilmiah Pendidikan Dasar, Vol. 3, No. 2, 2017, 120 131. Doi http://dx.doi.org/10.32332/elementary.v3i2.832.

Altan, Mustafa Zülküf. "Intelligence Reframed: Multiple Intelligences for the 21st Century by Howard Gardner", TESOL Quarterly, Vol. 35, No. 1, Spring 2001, http://www.jstor.org/stable/3587873, Accessed: 13/07/2018, 23:37.

Andriani, Durri., dkk. Metode Penelitian , Jakarta: Universitas Terbuka, 2011.

Arikunto, Suharsimi. Prosedur Penelitian Suatu Pendekatan Praktek, Jakarta: Rineka Cipta, 2002.

Astuti, Rahmani. Revolusi Belajar Untuk Anak: Panduan Belajar Sambil Bermain Untuk Membuka Pikiran Anak-Anak. Anda, Bandung: Kaifa, 2006.

Basid, Abdul, "Tadris al-Lughah al-'Arabiyyah 'ala Asas Ta'addud al-Dzaka': Bahtsun Tajribiy fi Madrasah Anak Shalih al-Ibtidaiyyah Malang”, Tesis, Universitas Islam Negeri Maulana Malik Ibrahim Malang, 2011.

Bakker, Anton., and Ahmad Charis Zubair. Metodologi Penelitian, Yogyakarta: Kanisius, 1992. 
Ara6iyât Jurnal Pendidikan Bahasa Arab dan Kebahasaaraban, 6 (1), 2019

Bauerlein, Mark. "More on Multiple Intelligences", The Wilson Quarterly (1976), Vol. 29, No. 1, Winter 2005, http:// wmw.jstor.org/stable/40261454", Accessed: 13/07/2015, 22:22.

Chaer, Abdul., and Leonie Agustina. Sosiolinguistik: Perkenalan Awal, Jakarta: Rineka Cipta, 1995.

Dardjowidjojo, Soenjono. Psikolinguistik: Pengantar Pemahaman Bahasa Manusia, Jakarta: Yayasan Obor Indonesia, 2003.

Dryden, Gordon., dan Jeanette Vos. The Learning Revolution: To Change The Way The World Learns, Selandia Baru: The Learning Web, 1999.

Dulay, Heidi., et.al. Language Two, Oxford: Oxford University Press, 1982.

Effendy, Ahmad Fuad. Metodologi Pengajaran Bahasa Arab, Malang: Misykat, 2005.

Emzir. Metodologi Penelitian Kualitatif: Analisis Data, Jakarta: Rajawali Press, 2010.

Farkhan, Muhammad. An Introduction To Linguistics, Jakarta: UIN Jakarta Press, 2006.

Gardner, Howard. Frames of Mind: The Theory of Multiple Intelligences, New York: Basic, 1983.

Gardner, Howard. Intelligence Reframed: Multiple Intelligences for the $21^{\text {st }}$ Century, New York: Basic, 2000.

Gardner, Howard. Multiple Intelligences: The Theory in Practice, New York: Basic, 1993.

Gardner, Howard dan Thomas Hatch, Multiple Intelligences Go to School: Educational Implications of the Theory of Multiple Intelligences, "Educational Researcher, Vol. 18, No. 8, Nov. 1989, 4-10", http://www.jstor.org/stable/ 1176460, Accessed: 13/07/2017 23:20.

Hamalik, Oemar. Media Pendidikan, Bandung: Citra Aditya, 2006.

Heriyanti. "Tadwir al-Mawad li Ta'lim Maharah al-Kitabah 'ala Asas al-Dhaka at alMuta'addidah bi al-Tatbiq 'ala Thalabah Madrasah al-Munirah al-Mutawasitah al-Islamiyyah Ujungpangkah Gresik”, Tesis, Pascasarjana Universitas Islam Negeri Maulana Malik Ibrahim Malang, 2016

Jago, Carol., Vicky Greenbaum, and Linda Hecker. "Multiple Intelligences", The English Journal, Vol. 85, No. 3, The Universe of Literature, March 1996, http://www.jstor.org/stable/820094, Accessed: 13/07/2016 22:16.

Kassell, Cathy. "Music and the Theory of Multiple Intelligences", Music Educators Journal, Vol. 84, No. 5, March 1998, http://www.jstor.org/stable/3399127, Accessed: 13/07/2016 23:18.

Kridalaksana, Harimurti. Kamus Linguistik, Jakarta: Gramedia, 1983.

McMahon, Susan D., Dale S. Rose, and Michaela Parks. "Multiple Intelligences and Reading Achievement: An Examination of the Teele Inventory of Multiple Intelligences", The Journal of Experimental Education, Vol. 73, No. 1, Fall, 2004, http://www.jstor.org/stable/20157383, Accessed: 13/07/2014 22:18. 
Ara6iyât Jurnal Pendidikan Bahasa Arab dan Kebahasaaraban, 6 (1), 2019

Mettetal, Gwendolyn., Cheryl Jordan, and Sheryll Harper. "Attitudes toward a Multiple Intelligences Curriculum", The Journal of Educational Research, Vol. 91, No. 2, Nov.-Dec. 1997, http://www.jstor.org/stable/27542138, Accessed: 13/07/2014 22:24.

Mulyasa, E. Kurikulum Berbasis Kompetensi, Bandung: Rosda Karya, 2006.

Mukminin, Amir, "I'dâd al-Mawâd al-Ta'limiyyah fi Mahârah al-Kalâm 'ala Asâs alDhakâât al-Muta'addidah bi Madrasah Wahid Hasyim al- Mutawasitah alIslamiyyah Ponorogo East Java", Disertasi, Universitas Islam Negeri Maulana Malik Ibrahim Malang, 2017.

Mu'min. "Manajemen Pembelajaran Berbasis Kecerdasan Majemuk: Studi Multisitus di SD Plus Mutiara Ilmu Bangil dan SD Mutiara Ilmu Pandaan”, Disertasi, Universitas Islam Negeri Maulana Malik Ibrahim Malang, 2016.

Muhajir, Noeng. Metode Penelitian Kualitatif, Yogyakarta: Rakesarasin, 2007.

Nata, Abudin. Metodologi Studi Islam, Jakarta: Raja Grafindo, 2014.

Pateda, Mansoer. Aspek-Aspek Psikolinguistik, Jakarta: Nusa Indah, 1990.

Rahardjo, Mudjia. Studi Kasus dalam Penelitian Kualitatif: Konsep dan Prosedurnya, Malang: UIN Maulana Malik Ibrahim, 2017.

Rayesh, Emir Eka Putra. "Hubungan Gaya Belajar dengan Multiple Intelligences Siswa Berprestasi Kelas IV dan V SD/MI di Kota Malang”, Tesis, Universitas Islam Negeri Maulana Malik Ibrahim Malang, 2016.

Samples, Bob. Open mind/Wholemind: Parenting and Teaching Tomorrow's Children Today, Torrance USA: Jalmar Press, 1999.

Shalahuddin, Mahfud. Media Pendidikan Agama, Bandung: Bina Islam, 2007.

Silberman, Melvin L. Active Learning: 101 Strategies to Teach Any Subject, Massachusettts: Allyn and Bacon Boston, 2006.

Sarjuli, et.al. Active Learning: 101 Strategi Pembelajaran Aktif, Yogyakarta. YAPPENDIS, 2007.

Sukmadinata, Nana Syaodih. Metode Penelitian Pendidikan, Bandung: Rosda Karya, 2011.

Tim PP Darul Muttaqien. Profil Pondok Pesantren Darul Muttaqien Parung Bogor, Bogor: PP Darul Muttaqien, 2015.

Tim PP Darul Muttaqien. Materi Orientasi Wali Santri TMI (Tarbiyatul Mu'allimin wal Mu'allimat al-Islamiyyah) Pesantren Darul Muttaqien: Satu dalam Aqidah, Toleransi dalam Khilafiyah, Berjama'ah dalam Ibadah, Bogor: DM Press, 2017.

Tarigan, Henry Guntur. Berbicara sebagai Suatu Keterampilan Berbahasa, Bandung: Angkasa Bandung, 2008.

Usman, Basyiruddin. Media Pembelajaran, Jakarta: Ciputat Press, 2007. 
Arabiyât Jurnal Pendidikan Bahasa Arab dan Kebahasaaraban, 6 (1), 2019

Worlds Translation Service. Revolusi Cara Belajar (The Learning Revolution) Belajar akan Efektif Kalau Anda dalam Keadaan Fun', Bagian I: Keajaiban Pikiran, Bandung: Kaifa, 2006.

Zuriah, Nurul. Metodologi Penelitian Sosial dan Pendidikan, Bandung: Bumi Aksara, 2006. 